\title{
Crime e castigo em Portugal e seu Império
}

\section{Maria Fernanda Baptista Bicalho}

Ordenações Filipinas. Livro V. Introdução, notas e cronologia de Silvia Hunold Lara. São Paulo: Companhia das Letras, 1999,510 páginas.

S e abrirmos o Livro V das Ordenaçôes Filipinas - publicado na coleção Retratos do Brasil, sob a cuidadosa organização de Silvia Hunold Lara - deparamo-nos com o desafio de um grande deslocamento. Deslocamento no tempo, nos princípios que regiam as condutas, as formas de pensar, de se inserir e de representar o mundo; deslocamento para um passado que, embora distante e profundamente distinto, tem sido largamente evocado, entre banalizações ingênuas e apropriaçôes indébitas, nesta onda febril das "Comemorações dos 500 anos dos Descobrimentos".

A introdução, cronologia e notas organizadas por Sílvia Lara nos guiam de forma reveladora e segura na interpretação do texto, na atribuição de sentido às palavras, às representaçóes e às práticas, na compreensão dos mecanismos sobre os quais se fundamentavam a Justiça régia, a Legislação, o Direito e as Instituições jurídicas portuguesas no reino e em suas conquistas ultramarinas. Desafiam-nos a inteligência da própria história, a faculdade de aprender, apreender ou compreender a estranha lógica do exercício da Justiça e do Poder nas sociedades no Antigo Regime.

Entre 1583 e 1585, nos tempos de União Ibérica, iniciou-se uma terceira compilação das leis civis, fiscais, administrativas, militares e penais portuguesas, ampliando as anteriores Ordenaçôes Manuelinas, incorporando algumas novidades jurídicas e administrativas, a criação de tribunais de justiça - como a Relação do Porto e a Casa de Suplicação - e a outorga de um novo regimento para o Desembargo do Paço. Sob o título Ordenaçôes e leis do reino de Portugal, recopiladas por mandado do muito alto, católico e 
poderoso rei dom Filipe, o primeiro, foram promulgadas em 1603, já sob o reinado de Felipe II. Constituíram, a partir de então, o corpo legal de referência para Portugal e suas colônias - no caso do Brasil vigoraram, grosso modo, até 1830 .

Compóem-se de cinco livros. $\mathrm{O}$ primeiro versa sobre as atribuiçóes, direitos e deveres dos magistrados e oficiais da justiça. $\mathrm{O}$ segundo define as relaçôes entre o Estado e a Igreja, os privilégios dos eclesiásticos e da nobreza, assim como os direitos e isenções fiscais de ambos. $\mathrm{O}$ terceiro trata de ações cíveis e criminais. $\mathrm{O}$ quarto legisla sobre o direito privado e individual — isto é, das coisas e pessoas —, estabelecendo regras para contratos, testamentos, tutelas, formas de distribuiçãao e aforamento de terras. O último e quinto livro - de que se trata aqui — é dedicado ao direito penal, estipulando os crimes e suas respectivas penas. $^{1}$

Ao abri-lo, podemos ler aleatoriamente: "Estabelecemos que toda pessoa, de qualquer qualidade ou condição que seja que....[fizer] alguma feitiçaria, morra morte natural...."; "qualquer que abrir... carta assinada por... [El-Rei], em que se contenham coisas de segredo.... que morra por isso...."; "toda pessoa... que pecado de sodomia por qualquer maneira cometer, seja queimado e feito por fogo em pó..."; e "qualquer cristão que tiver ajuntamento carnal com alguma moura ou com qualquer outra infiel... morra por isso...". Da mesma forma, "todo homem, de qualquer qualidade e condição que seja, que entrar em mosteiro de freiras de religião aprovada... morra por isso morte natural..."; "qualquer homem que dormir com sua filha ou com qualquer outra sua descendente, ou com sua mãe ou outra sua ascendente, sejam queimados e ela também, e ambos feitos por fogo em pó...."; "qualquer pessoa que matar outra ou mandar matar, morra por isso morte natural..."; e o "escravo... que matar seu senhor ou filho de seu senhor, seja atenazado e lhe sejam decepadas as mãos, e morra morte natural na forca para sempre...".

O espectro das "mil mortes" recai ainda sobre aqueles que se levantam ou se rebelam perante as Justiças; os que cometem crime de lesa-majestade; os que falsificam moedas ou o selo d'El-Rei; os que fabricam escrituras falsas; os que proferem falso testemunho; os que corrompem mercadorias e alteram 
pesos e medidas; os ladrões, os bígamos, os adúlteros, os alcoviteiros, e muitos outros.

Qual o significado de tanto rigor? Segundo Silvia Lara, "não se trata simplesmente de matar o criminoso, mas de relacionar a gravidade de sua falta ao rigor da punição, fazer com que o sofrimento do condenado inspire temor e sirva de exemplo, expiando suas culpas e restaurando o poder real violado pelo crime em toda a sua força e plenitude." 2 Restaurar o poder real em toda sua força e plenitude significava restaurar a função do soberano de representante da justiça, de árbitro dos conflitos sociais, de garante dos equilíbrios existentes. A Época Moderna conheceu o alargamento da administração ativa da Coroa e em última instância do rei. Árbitro supremo no campo da justiça, fundava-se nesta arbitragem a exclusividade régia de estabelecer lei geral para todo o reino, assim como a prerrogativa de criar magistrados e de vigiar o cumprimento de suas atribuições. As Ordenações são preciosos testemunhos do poder de intromissão e de regulamentação por parte da Coroa nas menores esferas e nas mais insólitas condutas e comportamentos dos súditos.
Paradoxalmente, no entanto, de acordo com a visão corporativa da sociedade que vigorava na época, o rei era visto como a cabeça do reino, o que apontava para uma concepção de certa forma limitada do poder régio: tão monstruoso como um corpo que se reduzisse à cabeça, seria uma sociedade em que o poder estivesse inteiramente concentrado no soberano. Nesse sentido, longe da concentração total e absoluta na figura do rei, o poder era, por natureza, repartido. Essa partilha deveria se traduzir na autonomia político-jurídica dos magistrados e das instituiçôes, cabendo ao monarca representar a unidade do corpo, mantendo seu equilíbrio, atribuindo a cada um aquilo que lhe era próprio, garantindo os estatutos, foros, direitos e privilégios estabelecidos na sociedade. ${ }^{3}$ Era corrente a idéia de que "o rei exerce um 'oficio', cujo fimé o bem comum, e que consiste na justiça e na governança segundo o direito, respeitando os foros das comunidades." ${ }^{4}$

Sem dúvida, a sistematização das leis representada pelas Ordenaçôes, longe de significar uma estratégia de imposição de limites ao poder monárquico - como nos poderiam sugerir as Constituiçôes escritas nas monarquias constitucio- 
nais - correspondia antes a um processo de afirmação do poder real. Embora tal afirmação não tenha se dado de forma eficaz e imediata sobre todo o território do Reino e seus domínios ultramarinos, havia, de fato, por parte da Coroa, uma vontade política neste sentido.

O próprio monarca carecia de instrumentos imediatos para uma brusca imposição de seu poder, pelo menos ao longo dos séculos XVI e XVII. Faltavam-lhe os meios institucionais, os meios humanos, o domínio efetivo do espaço e, inclusive, o monopólio dos próprios aparelhos de justiça. Para obter este monopólio era necessário enfrentar, ou submeter, dois ou três pólos concorrentes no seu exercício: o comunitarismo das justiças populares, baseadas nos usos e costumes das terras, e o corporativismo dos juristas letrados; além, é claro, das formas de justiça senhorial.

Um sensível contraponto às decisões centralizadoras ou arbitrárias do rei era personificado nos Conselhos ou Tribunais. A consulta a seus membros, juristas e letrados, era tida como indispensável à perfeição dos atos do monarca. Essa sistemática de governar por meio de consultas — daí a centralidade e a importância das consultas do Conselho Ultramarino na administração do Império - garantia a expressão de um ponto de vista "técnico" - e não despótico —, reafirmando o caráter corporativo do governo, reatualizando a imagem do rei como árbitro, mantenedor do equilíbrio e harmonia dos demais membros ou instituições do corpo político, mas de maneira nenhuma usurpador de suas funções.

Da mesma forma, para impor o seu poder a outros pólos políticos concorrentes, como as comunidades, o rei procurou criar novos dispositivos jurídicos e institucionais, ou seja, construir espaços de produção de poder nos quais a sua posição fosse mais favorável no sentido de estruturar seu próprio campo de ação. As Ordenações certamente constituíram um destes dispositivos. Mas não só. Como afirma Silvia Lara, "na administração do império português, por exemplo, a estrutura judicial confundia-se, na maior parte das vezes, com a burocracia colonial". 5

No campo da justiça, a administração régia apoiava-se, nas localidades, nos juízes de fora, personagens praticamente desconhecidos durante a Idade Média. A multipli- 
cação do cargo de juiz de fora em Portugal logo após a Restauração e nas conquistas ultramarinas em fins do século XVII - significou um instrumento que possibilitou a circulação do direito letrado e régio e dos padróes oficiais de julgamento, promovendo a desqualificação do sistema de justiça local, fundado em leis consuetudinárias, baseado nos usos e costumes da terra. $\mathrm{O}$ fato de a eles caber a presidência da Câmara municipal - substituindo o antigo juiz ordinário eleito pela comunidade - tornava-os instrumentos indispensáveis ao processo de centralização e de imposição da hegemonia legal e, portanto, monárquica, nos mais remotos confins do território luso e de seu ultramar.

A vontade ou a necessidade dessa imposição não era, no entanto, uma via de mão única, nem sempre correspondendo a uma iniciativa exclusivamente do governo central, partindo muitas vezes das próprias autoridades locais. Isso decorria do crescente prestígio da justiça real e da visão de mundo dos contemporâneos acerca da função arbitral da Coroa, a que se recorria para resolver conflitos domésticos entre facçôes rivais no seio da comunidade, ou entre seus representantes e os próprios agentes do poder central. Polêmicos e abundantemente tratados pela historiografia são os inúmeros conflitos de jurisdição na administração colonial, dando azo a que muitas vezes os historiadores os interpretem como reflexo da falta de regra e de norma da política portuguesa transplantada para os trópicos. Um deslocamento deste olhar, de forma mais atenta aos valores e às normas do Antigo Regime, poderia levar-nos a concluir que, disputando jurisdiçôes mal definidas, os administradores no ultramar eram obrigados a recorrer à arbitragem régia, legitimando e tornando diuturnamente presente o poder real naqueles longínquos domínios.

Voltando às Ordenaçôes, embora elas prescrevessem a pena de morte para um grande número de crimes, estudos recentes tendem à conclusão de que, em termos estatísticos, ela foi muito menos usada em Portugal do que poder-se-ia imaginar diante do rigorismo da lei escrita. Assim, através de uma relação dos presos da cadeia da cidade de Lisboa ao longo de dois anos, entre 1694 e 1696, o historiador português António Manuel Hespanha avalia as medidas penais aplicadas a cerca de 300 criminosos. A pena capital foi 
usada em apenas três casos, todos de homicídio. Outros crimes para os quais ela era prevista obtiveram penas relativamente mais leves, como a de degredo. Este foi imposto a um renegado e traidor, a um falsificador de moedas, a um salteador de estrada, a vários outros homicidas, a todos os condenados como ladrões, adúlteros, sodomitas, raptores, violadores, etc. $^{6}$

Um outro aspecto interessante que o autor apresenta — agora em termos diacrônicos - consiste no aumento efetivo, ao longo dos Setecentos, das execuções correspondentes à salvaguarda da ordem política e dos bens "públicos" — crimes políticos, religiosos e morais em contraposição às ofensas aos valores particulares ou aos bens "privados", como a vida, a honra, o patrimônio. Em outras palavras, o aumento em termos quantitativos da punição capital aos atentados de cunho político e aos valores públicos demonstra, ao fim e ao cabo, a afirmação do poder régio no campo não só da justiça, como também da ordem social e política na segunda metade do século XVIII em Portugal. $\mathrm{O}$ auge deste processo correspondeu ao advento do despotismo esclarecido do Marquês de Pombal, período no qual amiudaram-se consideravelmente os casos de punição exemplar e o recurso à pena capital, como demonstram as execuçóes dos implicados no atentado contra a vida de d. José, do Padre Malagrida, de alguns sediciosos no Reino e nas colônias, dentre outros.

Um terceiro ponto - e um dos mais interessantes - apontados por Silvia Lara na Introdução ao Livro V das Ordenaçôes, é o da estratégia dual do direito penal do Antigo Regime, da alquimia entre temor e amor na legitimação do poder do monarca. Em suas palavras, "infundindo respeito e temor, o castigo devia ser exemplar: a inscrição da vontade do soberano no corpo do condenado era também uma pedagogia de domínio, lição também aprendida por todos os que presenciavam o espetáculo penal. No mesmo registro, a comutação das penas e o perdão concedidos pelo monarca podiam ser usados com relativa freqüência a fim de que rigor e mercê se temperassem, construindo uma imagem paternal do soberano absoluto."

Se por um lado o rei era visto como dispensador de castigo — daí a utilização da denominação de "justiceiro", "cruel”, "terrível” —, por outro, sua imagem também se escul- 
pia na concessão do perdão ou, mais propriamente, no exercício da graça; perdão e graça vistos como regalias. Desta forma, a clemência como qualidade essencial dos reis constituía-se na outra face de intervenção da Coroa no processo de legitimação do seu poder. Consolidava-se, portanto, a imagem do rei como pai ou pastor dos súditos, a quem se devia amar, talvez mais do que temer. Segundo António Manuel Hespanha, "a mesma mão que ameaçava com castigos impiedosos, prodigalizava, chegando o momento, as medidas de graça. Por esta dialética do terror e da clemência, o rei constituía-se, ao mesmo tempo, em senhor da Justiça e mediador da Graça. Se investia no temor, não investia menos no amor."

Castigo e misericórdia: ambas estratégias de afirmação do poder real. Remetendo-se à sentença proferida para os réus da Inconfidência — e à condenação de Tiradentes à forca, para que nela morresse "morte natural para sempre” - Sílvia Lara enfatiza a comutação da pena de morte em degredo perpétuo para a África dos outros onze condenados. O episódio evoca o ritual das "mil mortes" em toda a sua plenitude: "tanto a clemência da rainha para com os outros onze condenados à morte como a execução exemplar de um único réu constituem faces do mesmo ritual de afirmação da glória soberana." " A graça era, portanto, um dos componentes da justiça régia, um dom que dependia da liberalidade do rei — ou da rainha.

Assim sendo, a realização da Justiça - principal função dos reis nas sociedades de Antigo Regime exigia uma estratégia plural que, ao lado das punições, dos castigos e das penas, prescrevia o perdão, a graça, o prêmio, a mercê, o dom. Em punir e agraciar - assim como em reconhecer a posição, os méritos, os serviços e fazer mercê aos súditos dividiam-se as estratégias de afirmação do poder real. Este apresentavase de formas múltiplas, impondo-se a uma sociedade baseada em múltiplas hierarquias.

O Livro V das Ordenaçôes oportunamente reeditado com a criteriosa análise de Silvia Hunold Lara - vem nos desvendar um dos caminhos de apreensão daquela sociedade, através do emaranhado de seus crimes e castigos. Esperamos sinceramente que outras obras da mesma importância ou do mesmo porte sejam também editadas, e tão bem comentadas. Só assim o desafio de 
compreensão do passado poderá se transmutar no desafio muito maior de construção do futuro. E então poderemos comemorar esses "nossos" 500 anos...

\section{Notas}

${ }^{1}$ LARA, Silvia H. "Introdução" in Ordenaçôes Filipinas. Livro V. São Paulo: Companhia das Letras, 1999, p. 34-35.

${ }^{2}$ Idem, p. 22.

3 HESPANHA, António Manuel e XAVIER, Ângela Barreto. "A Representa- ção da Sociedade e do Poder" in MATTOSO, José (dir.) História de Portugal. O Antigo Regime (162-1807). Volume 4. Lisboa: Editorial Estampa, 1993, p. 123.

${ }^{4}$ GODINHO, Vitorino Magalhães "Finanças Públicas e Estrutura do Estado" in Ensaios II. Sobre a História de Portugal. 2.a ed. Lisboa: Livraria Sá da Costa Ed., 1978.

${ }^{5}$ LARA, Silvia H. "Introdução..., p. 25.

${ }^{6}$ HESPANHA, António M. "A Punição e a Graça” in MATTOSO, op. cit., p. 240.

${ }^{7}$ LARA, Silvia H. "Introdução..., p. 24.

${ }^{8}$ HESPANHA, António M. "A Punição..., op. cit., p. 248.

${ }^{9}$ LARA, Sílvia H. “Introdução..., p. 28. 